International

Medical Society

http://imedicalsociety.org

\title{
Accidents by Sharp Instruments of Nursing Professionals in a Hospital Unit

\section{Abstract}

Objective: To analyze the records of work accidents involving nursing professionals by sharp instruments according to the Notifiable Diseases Information System (SINAN).

Method: Descriptive and documentary research with a quantitative approach, performed in an Emergency and Trauma Hospital in a Northeast Brazil city in May 2015. Data collection was conducted from work accident records maintained by the Epidemiology sector of the hospital, for the period from 2010 to 2014. The sample was the result of 152 forms.

Results: The highest prevalence year of accidents in nursing professionals with sharp instruments was 2014 with 57 cases. On the types of exposure involving biological materials, contact with blood remains the organic material where professionals are more vulnerable to contamination. Situations leading sharp injuries are intravenous drugs (14\%), followed by a venous/arterial puncture for blood collection (14\%), the venous/arterial puncture unspecified (17.5\%) and by improper disposal of sharps in the workbenches, beds, or on the floor (12.25\%). As regards the causal agent of biological material by accident, there is a prevalence of accidents involving lumen needles, especially between 2013 (51.3\%) and 2014 (61.25\%).

Conclusion: This study enabled to understand better the importance records with accidents caused by sharp instruments and the importance of the indicators analysis so preventive measures can be implemented and the occurrence of accidents are minimized through preventive actions.
Davydson Gouveia Santos', Soraya Maria de Medeiros ${ }^{2}$, Ana Elisa Pereira Chaves ${ }^{3}$, Yanna Gomes de Sousa4, Ana Carolina Ribeiro Silva 5 , Rejane Maria Paiva de Menezes ${ }^{2}$, Marília Souto de Araújo 6

1 Nurse. Graduated by União de Ensino Superior de Campina Grande/UNESC. Campina Grande (PB), Brazil.

2 Nurse. Ph.D. in Nursing. Professor of the Department of Nursing, Federal University of Rio Grande do Norte/ UFRN. Natal (RN), Brazil.

3 Nurse. Ph.D. student of the Graduate Program in Nursing, Federal University of Rio Grande do Norte/UFRN. Natal (RN), Brazil.

4 Nurse. Master student of the Graduate Program in Nursing, Federal University of Rio Grande do Norte/UFRN. Natal (RN), Brazil.

5 Nurse. Graduate by União de Ensino Superior de Campina Grande/UNESC. Campina Grande (PB), Brazil.

6 Nursing Student by the Federal University of Rio Grande do Norte/ UFRN. Natal (RN), Brazil.

Contact information:

Yanna Gomes de Sousa.

Đyanna_gomes@yahoo.com.br

\section{Keywords}

Occupational Accidents; Sharp instruments; Nursing professionals. 


\section{Introduction}

Historically, workers have suffered many misfortunes in the workplace, with big repercussions in the social, economic and health area. Their exposure to physical, chemical, biological, ergonomic, psychosocial risks and accidents arising from their work can result in diseases and occupational problems [1].

The work-related injuries come from diseases and accidents affecting the population in general, but particularly acquiring different characteristics in certain workers categories [2].

Among the international organizations, the Center for Disease Control and Prevention (CDC) defines health workers as everyone (employees, students, office clerks, public health workers or volunteers) who perform activities that involve contact with patients or with blood or with body fluids of patients admitted in the laboratory or health surveillance [3]

Among the health professionals' workplaces, chemical, physical, biological, psychosocial, ergonomic agents and accidents [4] highlight the hospital because of the several work activities that expose workers to the risks caused. This diversity of risks predisposes to illness at work that causes the work accident.

In the hospital context, nursing professionals have been more susceptible to victimization by sharps injuries due to the large number of tasks they perform using needles, catheters and often not using Personal Protective Equipment (PPE), mainly gloves, which do not prevent the accident, but enshrine that large volume of blood comes in direct contact with the skin [5].

For reporting and analysis purposes, the sharps are responsible for serious accidents with biological material in hospitals, generating some consequences, since the individual has a risk of disease. Thus, data show high rates of accidents [6].

About diseases acquired through accidents with the biological material; hepatitis B is the greatest risk. The incidence of transmission among workers exposed to this virus ranges from $6 \%$ to $30 \%$, rea- ching up to $60 \%$ depending on the source patient situation, concerning hepatitis $C$, the risk of transmission of percutaneous exposure to the biological material, is approximately $1.8 \%$, ranging from $0 \%$ to $7 \%$. About HIV, it is estimated at $0.3 \%$ the risk of contamination after percutaneous $0.09 \%$ and the mucocutaneous risk exposure [7].

Even HIV, whose risk of occupational transmission is only $0.3 \%$ of percutaneous injuries caused infections in 57 health workers in the United States in 2001 [8]

In Brazil, the number of work accidents shows the growing form of illness and absenteeism among health professionals, so it is considered a major public health problem as well as causing damage to workers and employers, affecting the economy of the country. Thus, it is soon deserved analysis aspect for better understanding and control of risks. However, the knowledge of the magnitude of the problem is still quite limited and runs counter to the implementation of specific actions in the promotion and prevention of damage to the health of workers [9].

Within each context surrounding the occurrence and formal knowledge of occupational accidents in Brazil, the underreporting of such accidents is recognized as an obstacle to the planning of occupational health surveillance actions. Studies [10, $11,12,13]$ show that the published statistics do not correspond to the total number of accidents and deaths, and even the Ministry of Social Security states that the real figures are underestimated.

To avoid such underreporting, it is needed complete, updated and reliable information on the occurrence of accidents and illnesses to which workers are subject to the exercise of their profession, to the orientation of measures to minimize such events and subsidize the development of targeted policies on the working class so often victims of accidents and occupational diseases [9, 14].

Considering the magnitude and importance of this theme, it was aimed to present the study to 
analyze the records of work accidents with active nurses caused by sharp instruments in a hospital in northeastern Brazil.

\section{Method}

Cross-sectional study with secondary data on sharps injuries that occurred in 2010 to 2014 in an Emergency and Trauma Hospital in the interior of Paraíba in northeastern Brazil, the data were derived from the epidemiology sector through the notification of this disease in SINAN is part of the UHS information system from an ongoing process of collection, transmission and dissemination of information in terms of reportable diseases and accidents, constituting a fundamental tool of the epidemiological surveillance system [15].

The Emergency and Trauma Hospital where the research was conducted has several specialties such as: Surgery, Internal Medicine, Dermatology, Physiotherapy, Gynecology, Neurology, Dentistry, Pediatrics, Psychology, Radiology, Social Services, Basic Services, Adult ICU, Children's ICU with reference units and Intensive Treatments ensuring the rehabilitation and recovery of patients who require 24 hours services. Around 300 new patients are assisted per day. Forms of SINAN were studied Accidents with Exposure to Biological Materials in sharps injuries in the Epidemiology sector of the Hospital. This department operates 24 hours a day consisting of a multidisciplinary team.

The inclusion criteria were all cases of occupational accidents with sharp instruments recorded in SINAN between 2010 and 2014 with nursing professionals. Erased damaged forms or with any illegibility that prevented data collection were excluded. The resulting sample was 152 forms that met the inclusion criteria.

The data in the records were exported and tabulated by TabWin version 3.6, linked to SINAN-NET, and Microsoft Office Excel 2010. For the analysis, a descriptive statistics was performed through abso- lute and relative frequency measures and presentation of data in tables.

The research was submitted to the Research Ethics Committee - REC of the State University of Paraíba - UEPB for consideration and it was approved by CAAE: 44388115.3.0000.5187. The main researcher signed the Commitment Agreement for Use Data File and the agreed to meet the standards of Resolution 466/12 of the National Health Council, highlighting the study purposes, identification, research contacts and ensuring confidentiality of information.

\section{Results}

A study was conducted to examine the records of work accidents caused by sharp instruments occurred with nursing professionals - nursing technicians and nurses - operating in a hospital in northeastern Brazil, which analyzed 152 case of work accidents reported in the System for Notifiable Diseases Information System (SINAN), in the period 2010-2014.

It was found in this study that 2014 was the highest prevalence year of accidents in nursing professionals with sharp instruments, obtaining 57 cases. It is noteworthy that in 2010-2014, the category with the highest number of accidents was nursing technicians with 114 cases. Regarding gender, there is a predominance in female professionals (Table 1).

On the types of exposure involving biological materials, materials that involve risks for the nursing team professionals are presented in Table 2. It is observed repetition of values regarding the exposed tissue (percutaneous and full skin).

About organic materials that professionals are exposed (Table 3), the contact with blood is the organic material that professionals are most vulnerable to contamination. It is observed that between 2012 and 2013 , an increase of $10.47 \%$ while there was a considerable decrease in 2014 (61.25\%).

Regarding the circumstances of the accident, the types of procedures performed by the nursing team 
Table 1. Distribution of accidents by nurses and patients (n=152). Paraíba, Brazil, 2010-2014.

\begin{tabular}{|c|c|c|c|c|c|c|c|}
\hline & \multicolumn{3}{|c|}{ Nursing team } & \multicolumn{3}{c|}{ Gender } \\
\cline { 2 - 7 } & N.T. & Nurse & Total & Male & Female & Total \\
\hline 2010 & $\mathrm{n}(\%)$ & $\mathrm{n}(\%)$ & $\mathrm{n}(\%)$ & $\mathrm{n}(\%)$ & $\mathrm{n}(\%)$ & $2(100)$ \\
\hline 2011 & $22(100)$ & $-(-)$ & $2(100)$ & $-(-)$ & $2(100)$ & $24(85.68)$ & $28(100)$ \\
\hline 2012 & $24(85.68)$ & $4(14.28)$ & $28(100)$ & $-(-)$ & $28(100)$ & $28(100)$ \\
\hline 2013 & $30(81)$ & $7(18.9)$ & $37(100)$ & $3(8.1)$ & $34(91.8)$ & $37(100)$ \\
\hline 2014 & $36(63)$ & $21(36.75)$ & $57(100)$ & $2(3.5)$ & $55(96.25)$ & $57(100)$
\end{tabular}

N.T.: Nursing Technicians. Source: Research data

Table 2. Type of exposure involving biological material (n=152). Paraíba. Brazil. 2010-2014.

\begin{tabular}{|c|c|c|c|c|c|c|}
\hline & & & Type of & osure & & \\
\hline & Percutaneous & Full skin & Not full skin & Other & Not informed & Total \\
\hline & n (\%) & n (\%) & n (\%) & n (\%) & n (\%) & n (\%) \\
\hline 2010 & $1(50)$ & $1(50)$ & $-(-)$ & $-(-)$ & $-(-)$ & $2(100)$ \\
\hline 2011 & $18(54.54)$ & $11(33.33)$ & $-(-)$ & $1(3.03)$ & $3(9.09)$ & $33(100)$ \\
\hline 2012 & $18(45)$ & $16(40)$ & $3(7.5)$ & $3(7.5)$ & $-(-)$ & 40 (100) \\
\hline 2013 & $24(46.08)$ & $26(49.92)$ & $1(1.92)$ & $-(-)$ & $1(1.92)$ & $52(100)$ \\
\hline 2014 & $32(44.80)$ & $35(49)$ & $-(-)$ & $1(1.40)$ & $3(4.2)$ & $71(100)$ \\
\hline
\end{tabular}

Table 3. Numerical distribution of organic materials that professional category is exposed ( $n=152)$. Paraíba. Brazil. 2010-2014.

\begin{tabular}{|c|c|c|c|c|c|c|c|}
\hline & \multicolumn{7}{|c|}{ Organic Material } \\
\cline { 2 - 8 } & Blood & $\begin{array}{c}\text { Cerebrospinal } \\
\text { fluid }\end{array}$ & $\begin{array}{c}\text { Cerebrospinal fluid } \\
\text { with blood }\end{array}$ & Other & Ignored & Not informed & Total \\
\hline 2010 & $\mathrm{n}(\%)$ & $\mathrm{n}(\%)$ & $\mathrm{n}(\%)$ & $\mathrm{n}(\%)$ & $\mathrm{n}(\%)$ & $\mathrm{n}(\%)$ & $\mathrm{n}(\%)$ \\
\hline 2011 & $17(60)$ & $-(-)$ & $-(-)$ & $-(-)$ & $1(50)$ & $-(-)$ & $2(100)$ \\
\hline 2012 & $19(67.83)$ & $-(-)$ & $3(10.71)$ & $3(10.71)$ & $1(3.57)$ & $2(7.14)$ & $28(100)$ \\
\hline 2013 & $29(78.3)$ & $-(-)$ & $2(5.4)$ & $2(5.4)$ & $1(2.7)$ & $3(8.1)$ & $37(100)$ \\
\hline 2014 & $35(61.25)$ & $-(-)$ & $1(1.75)$ & $9(15.75)$ & $3(5.25)$ & $9(15.75)$ & $57(100)$ \\
\hline
\end{tabular}

that causes accidents with sharp instruments are exposed (Table 4).

According to the occurrence of sharp injuries, it is seen that mostly occurred in 2014, when nursing workers were administering intravenous drugs (14\%), followed by venous/arterial puncture for blood (14\%), the unspecified venous/arterial punctu- re $(17.5 \%)$ and the improper disposal of sharps in the workbench, beds, or on the floor (12.25\%).

As regards the causing agent of the accident by biological materials (Table 5), there is the prevalence of accidents involving lumen needles, especially between 2013 (51.3\%) and 2014 (61.25\%). 
Table 4. Distribution of the circumstances that caused the accident at work $(n=152)$. Paraíba, Brazil, 2010-2014

\begin{tabular}{|c|c|c|c|c|c|}
\hline & & Acc & nt circums & ces & \\
\hline & 2010 & 2011 & 2012 & 2013 & 2014 \\
\hline & n (\%) & n (\%) & n (\%) & n (\%) & $n(\%)$ \\
\hline Intravenous medication administration & $1(50)$ & $1(3.57)$ & $2(7.14)$ & $1(2.7)$ & $8(14)$ \\
\hline Intramuscular medication administration & $-(-)$ & $1(3.57)$ & $1(3.57)$ & $-(-)$ & $-(-)$ \\
\hline Subcutaneous medication administration & $-(-)$ & $2(7.14)$ & $-(-)$ & $1(2.7)$ & $3(5.25)$ \\
\hline Venous/arterial puncture for blood & $-(-)$ & $1(3.57)$ & $1(3.57)$ & $1(2.7)$ & $8(14)$ \\
\hline Unspecified venous/arterial puncture & $-(-)$ & $1(3.57)$ & $4(14.28)$ & $9(24.3)$ & $10(17.5)$ \\
\hline $\begin{array}{l}\text { Improper disposal of sharps materials like } \\
\text { workbenches, bed, floor }\end{array}$ & $-(-)$ & $4(14.28)$ & $6(21.42)$ & $4(10.8)$ & $7(12.25)$ \\
\hline Not informed disposal of sharps materials & $-(-)$ & $3(10.71)$ & $-(-)$ & $-(-)$ & $-(-)$ \\
\hline Disposal of sharp material in garbage bag & $-(-)$ & $-(-)$ & $1(3.57)$ & $2(5.4)$ & $-(-)$ \\
\hline Boxes handling with sharp equipment & $-(-)$ & $4(14.28)$ & $1(3.57)$ & $2(5.4)$ & $1(1.75)$ \\
\hline Surgical procedure & $-(-)$ & $-(-)$ & $-(-)$ & $2(5.4)$ & $1(1.75)$ \\
\hline Laboratory procedure & $-(-)$ & $-(-)$ & $-(-)$ & $1(2.7)$ & $-(-)$ \\
\hline Dexterous & $-(-)$ & $-(-)$ & $-(-)$ & $-(-)$ & $2(3.5)$ \\
\hline Recapping & $-(-)$ & $2(7.14)$ & $2(7.14)$ & $2(5.4)$ & $3(5.25)$ \\
\hline Other & $-(-)$ & $9(32.13)$ & $6(21.42)$ & $10(27)$ & $10(17.5)$ \\
\hline Other equipment & $1(50)$ & $-(-)$ & $-(-)$ & $-(-)$ & $-(-)$ \\
\hline Not informed & $-(-)$ & $-(-)$ & $4(14.28)$ & $2(5.4)$ & $4(7)$ \\
\hline Total & $2(100)$ & 28 (100) & $28(100)$ & 37 (100) & $57(100)$ \\
\hline
\end{tabular}

Table 5. Numerical distribution of cause agents of occupational accidents ( $n=57)$. Paraíba, Brazil, 20102014.

\begin{tabular}{|c|c|c|c|c|c|c|c|}
\hline & & & Acciden & causes & & & \\
\hline & Needle with lumen & Needle without lumen & Blade & Other & Ignored & Not informed & Total \\
\hline & n (\%) & n (\%) & n (\%) & n (\%) & n (\%) & n (\%) & n (\%) \\
\hline 2010 & $2(100)$ & $-(-)$ & $-(-)$ & $-(-)$ & $-(-)$ & $-(-)$ & $2(100)$ \\
\hline 2011 & $13(46.41)$ & $1(3.57)$ & $3(10.71)$ & 7 (24.99) & $1(3.57)$ & $3(10.71)$ & $20(100)$ \\
\hline 2012 & $16(57.12)$ & $3(10.71)$ & $4(14.28)$ & $-(-)$ & $-(-)$ & $5(17.85)$ & $28(100)$ \\
\hline 2013 & 19 (51.3) & 8 (21.6) & $3(8.1)$ & $1(2.7)$ & $1(2.7)$ & $5(13.5)$ & 37 (100) \\
\hline 2014 & $35(61.25)$ & $1(1.75)$ & $9(15.75)$ & $4(7)$ & $-(-)$ & $8(14)$ & $57(100)$ \\
\hline
\end{tabular}




\section{Discussion}

When analyzing the number of work accidents recorded in SINAN in 2010-2014 with nursing professionals, it was found higher occurrence in the category of nursing technicians. Regarding gender and marital status, the results are consistent with national studies showing that nursing is an essentially female profession [16]. This proves that the number of women is considerably higher in hospitals, since, before the historical process women are still a plurality in the care process, thus demonstrating their sensitivity [17].

During the care performance in the hospital, nurses and nursing technicians face hard work to exercise continuously and nursing care surveillance, sometimes acting quickly because of a big number of patients and clinical and emergency complications caused by the change of state of health and it facilitates the occurrence of accidents with sharps.

Studies [18, 19, 20, 21, 22] conducted in health professionals in Brazil and other countries highlighted the nursing staff as the most injured during professional practice, with the greatest risk factor contact with sharps and potentially contaminated biological materials. Among the reasons given for greater vulnerability of nursing staff are the characteristics of the profession, as being the largest individual group of health professionals responsible for uninterrupted 24 hours a day service and perform a higher volume of direct patient care.

A study [23, 24] performed with medical professionals of an emergency service highlights that the higher the workload shift, the greater the risk of accidents. Among the work accidents caused in the medical staff, those to the emergency scene $(n=454,51.7 \%)$ and during transportation of the victim $(n=256)$ were highlighted.

The Occupational Safety and Health Administration (OSHA) define a normal work shift as a work period of no more than eight consecutive hours during the day, five days a week with at least an eight-hour period of rest [25]. EMS workers are of- ten scheduled to work extended shifts of $>12$ hours. Extended shifts increase the risk of adverse events, medical errors and attention deficits in diverse settings, including healthcare [26].

The working conditions offered by many hospitals is a determining factor for the increase in cases, causing the risk of accidents present in the activities of health professionals, making nursing workers the most vulnerable class [27].

The work environment offers multiple risks to nursing professionals, especially the danger of sharp materials in the type of exposure to biological material observed in Table 2 the great problem of exposure to biological fluids, percutaneous being the predominant among these workers.

Percutaneous exposures are injuries caused by perforating or cutting instruments that are common in the nursing team from the handling of needles, blades and objects that pierce or cut [28].

Biological materials which nursing professionals are more exposed are blood, cerebrospinal fluid and cerebrospinal fluid with blood. This demonstrates that the biological risks have extreme relation to the procedures that nursing performs.

Therefore, the adoption of safe practices in the exercise of nursing activities needs to be a subject to be thoroughly discussed by the team responsible for the continuing education actions, as also, they need to discover the reason for not following the recommendations standard by professionals who know them, however, not properly practice [29].

In the distribution of the circumstances that caused the accident at work in this study, seems that administration of intravenous drugs (14\%) had a higher percentage, followed by venous/arterial puncture for blood collection (14\%), unspecified venous/ arterial puncture (17.5\%) and improper disposal of sharps in the workbenches, beds, or on the floor (12.25\%).

Several studies $[30,31,32]$ reported that most of the activities performed by the nursing team focus on direct patient care with invasive nature, which 
can increase the risk of accidents, for example, during venipuncture, dilution and administration of medicines, which involve needles or sharps material.

Table 5 showed that the sharp materials are causing most accidents are needles with the lumen justified that among the activities carried out by nursing professionals, this equipment is essential for medication administration. Injuries involving needles are considered harmful and with great potential for disease transmission.

Direct patient care associated with the administration of drugs and, consequently, to contact with sharps, predisposes to the occurrence of accidents, especially when patients exhibit aggressive behavior and customer condition requiring emergency assistance [33].

The nursing professionals for working in an unhealthy environment perform procedures with a risk of accidents when handling sharps improperly, leaving them on workbenches, beds, floors, performing unnecessary recapping, discarding materials in inappropriate places and other favorable situations for accidents. Also, the high complexity of activities performed within the hospital makes the nursing professional vulnerable to accidents [34].

The work accident with needles and sharp instruments originates changes in professional physical structure by the perforations and cuts caused by such materials. Indeed, it can cause biological changes due to possible infection with hepatitis $B$, $C$, and AIDS. These experiences can provide the manifestation of feelings such as fear, anguish, despair, anxiety and stress [35].

The PPE (Personal Protective Equipment) aims to protect against risks that threaten the safety and health while reducing the exposure of professional biological agents, recommended for the use and disposal of sharps [36]. Thus, health education activities need to emphasize the correct use of personal protective equipment (PPE) $[9,37]$, the discussion of each function and the essentiality of its use. They also need to explain why there are containers for the disposal of sharps and needles instruments and the need to prevent their overcrowding, as preventing accidents.

\section{Prevention of Work Accidents in the hospital}

The main objective of a hospital is to provide services in the health are with quality, efficiency, and effectiveness. This goal cannot be achieved without the effective administration of an accident prevention program that provides safe environmental conditions for the patient and the professional. All levels of management must constantly strengthen the rules and safety regulations, be alert and identify unsafe practices and conditions, taking immediate action to correct irregularities [38]

The organization of work reduces the chances of avoiding risks, mitigating them or eliminating them while performing its duties. Occupational Risk is any possibility that some element or existing circumstances in a given process or work environment can cause damage to health, whether through accident, disease or the suffering of workers [39].

According to the International Labor Organization, the detection of risks and risk assessment must be considered to identify what could affect the employees and the property, to develop and implement appropriate prevention and protection measures [40]

Ordinance number. 3214 of June 8, 1978, of the Ministry of Labor and Employment -MTE ensures the right of workers to the Occupational Safety and Health at Work in Brazil. Through the Regulatory Standards- RS, the Specialized Safety and Medical Engineering work (SESMT) and Internal Commissions for accident prevention (CIPA) were established that are instruments that workers and companies have to deal with the prevention of accidents and the conditions of the working environment. These bodies protect the physical integrity of the employee and every aspect that can potentially affect his health.

Hospital managers and health professionals gui- 
ded by the technical team of SESMT need to adopt reduction of occupational accidents policy in the hospital. Thus, they need to adopt the following strategies to help minimize occupational risks: Periodically review the equipment and personal protection equipment - PPE; Schedule preventive maintenance of machinery and equipment; Implement accident prevention lecture programs; Unify health and safety procedures in the hospital; Create calendar support to prevent accidents; Improve the internal policies of occupational safety; and Creating a culture of safety at work.

The effective workers' participation in the adoption of measures to prevent accidents to their integrity reduces costs of prevention, improves working conditions, product quality, and process productivity. The educational practice should be held in accessible language emphasizing the activities that the company develops and its inherent risks. Thus, the worker shall be able to collaborate in the promotion of working conditions and provide hospital company grants to improve the tactical, strategic and operational planning. The awareness by workers and hospital managers regarding health and safety in the production process can come to ensure the best quality of the work environment. Thus, a network of solidarity is installed, creating conditions for other health actions, adding quality of life to the worker [41].

\section{Conclusion}

It was found in this study that the work done by nursing professionals gives various occupational risks, especially accidents with sharps.

Given this problem, it is pertinent to point out that a good working condition can become timely and provide a decrease in the number of accidents involving the use of needles and sharps.

There is also the need for implementation of ongoing education of these professionals and to workers' health, including the risks and prevention of occupational accidents, use of personal protective equipment and collective importance of prompt reporting and serologic follow-up within the institution. This will involve directly in decreasing the rates of accidents and/or occupational diseases.

Therefore, it is important that the hospital and the healthcare professional are united in the creation of prevention and elimination of risks by continuing educational activities that enlighten and sensitize the workers to know their work environment and the factors that interfere with their health.It is understood that security is a responsibility of all.

\section{References}

1. Aragón A, Partanen T, Felknor S, Corriols M. Social determinants of workers' health in Central America. International Journal of Occupational and Environmental Health. 2011; 17(3):230-7.

2. Ministério da Saúde (Brasil). Rede Nacional de Atenção Integral à Saúde do Trabalhador. Manual de Gestão e Gerenciamento. Brasília: Ministério da Saúde; 2006.

3. Centers For Disease Control And Prevention. Updated U.S. Public Health Service Guidelines for the Management of Occupational Exposures to HBV, HCV, and HIV and Recommendations for Postexposure Prophylaxis. MMWR 2001; 50. [acesso em 2016 fev 14]. Disponível em www.cdc.gov.

4. Manetti ML, Costa JCS, Marziale MHP, Trovó ME. Prevenção de acidentes de trabalho com material biológico segundo o Modelo de Green e Kreuter. Rev Gaúcha Enferm, Porto Alegre (RS) 2006 mar; 27(1):80-91.

5. Shimizu HE, Ribeiro EJG. Ocorrência de acidente de trabalho por materiais perfurocortantes e fluidos biológicos em estudantes e trabalhadores da saúde de um hospital escola de Brasília. Rev Esc Enferm USP. 2002; 36(4):367-75.

6. Lubenou JAM, Moura MEB. Representações sociais sobre as causas dos acidentes com materiais perfurocortantes por técnicos de enfermagem. Rev. Rene. 2012; 13: 1132-41. Disponível em: http://www.scielo.br/pdf/rlae/v20n6/pt 21.pdf. Acesso em: 06 mar 2015.

7. CDC. Public Health Service Guidelines for Management of Occupational Exposures to HIV Recommendations for Postexposure Prophylaxis. MMWR 54: 1-17, 2005.

8. Cavalcante CAA, Medeiros SM, Mata MS, Cavalcante EFO, Cavalcante ES, Veríssimo e Oliveira E. Serious work accidents in Rio Grande do Norte: a cross sectional study. Online Brazilian Journal of Nursing, 2015; 14 (4): 543-55. 
9. Centers For Disease Control And Prevention. Surveillance of Healthcare Personnel with HIVIAIDS, as of December 2002. 2002 dez. [acesso em 2016 Jan 10]. Disponível em www.cdc. gov/ncidod/hip/blood/ hivpersonnel.htm

10. International Labour Organization (ILO). Labour Administration and Inspection Programme: The prevention of occupational diseases. Geneva: ILO; 2013.

11. Galdino A, Santana V S, Ferrite S. Os Centros de Referência em Saúde do Trabalhador e a notificação de acidentes de trabalho no Brasil. Cad. Saúde Pública, 2012; 28(1):145-59.

12. Chagas AMR, Salim CA, Servo LMS (org). Saúde e segurança no trabalho no Brasil: aspectos institucionais, sistemas de informação e indicadores. Brasília: Ipea, 2011.

13. Bortoleto MSS, Nunes EFPA, Haddad MCL, Reis GAX. Acidentes de trabalho em um pronto atendimento do Sistema único de saúde. Revista Espaço para a Saúde. 2011; 13(1):91-7.

14. Chagas AMR, Salim CA, Servo LMS (org). Saúde e segurança no trabalho no Brasil: aspectos institucionais, sistemas de informação e indicadores. Brasília: Ipea, 2011.

15. Ministério da Saúde (Brasil). Rede Nacional de Atenção Integral à Saúde do Trabalhador. Manual de Gestão e Gerenciamento. Brasília: Ministério da Saúde; 2006.

16. Dalri RCMB. Carga horária de trabalho dos enfermeiros de emergência e sua relação com o estresse e cortisol salivar. $201 \mathrm{f}$. Tese (Doutorado). Universidade de São Paulo. Ribeirão Preto, 2013.

17. Magagnini MAM, Ayres JA. Acidentes com material biológico: realidade de uma instituição hospitalar do interior paulista. Rev. Min de Enf. 2009; 13: 123-130.

18. Balsamo AC, Felli VEA. Estudo sobre os acidentes de trabalho com exposição aos líquidos corporais humanos em trabalhadores da saúde de um hospital universitário. Rev Latino-am Enfermagem. 2006; 14(3):346-53.

19. Tabak N, Shiaabana AM, Shasha S. The health beliefs of hospital staff and the reporting of needlestick injury. J. Clin Nurs. 2006; 15 (10): 1228-39.

20. Falagas ME, Karydis I, Kostogiannou I. Percutaneous exposure incidents of the health care personnel in a newly founded tertiary hospital: a prospective study. Plos One. 2007; 2 (2): 194.

21. Venier $A G$ et al. Surveillance of ocupacional blood and body fluid exposures among French health care workers in 2004. Infect Control Hosp Epidemiol. 2007; 28(10): 1196-201.

22. Chiodi MB et al. Acidentes registrados no Centro de Referência em Saúde do Trabalhador de Ribeirão Preto, São Paulo. Rev Gaúcha Enf. 2010; 31(2): 211-17.

23. Weaver MD, et al. An observational study of shift length, crew familiarity, and occupational injury and illness in emergency medical services workers. Occup Environ Med 2015; 72:798804. doi:10.1136/oemed-2015-102966

24. Williamson A, Lombardi DA, Folkard $S$, et al. The link between fatigue and safety. Accid Anal Prev 2011; 43:498-515.
25. Occupational Safety and Health Administration. "Frequently Asked Questions: Extended Unusual Work Shifts". United States Department of Labor. www.osha.gov/OshDoc/data Hurricane Facts/faq longhours.html (accessed 1 Jun 2014).

26. Wagstaff AS, Sigstad Lie JA. Shift and night work and long working hours-a systematic review of safety implications. Scand J Work Environ Health 2011; 37:173-85.

27. Marziale MH. Subnotificação de acidentes com perfurocortantes na enfermagem. Rev. Bras Enferm. 2003; 56: 164-168.

28. Brasil. Ministério da Saúde. Secretaria de Atenção à Saúde. Departamento de Ações Programáticas Estratégicas. Exposição a materiais biológicos. Brasília: Editora Ministério da Saúde, 2006. $76 p$

29. Lima FA et al. Acidentes Perfurocortante e Profissionais de Enfermagem. Esc Anna Nery R Enferm. 2007; 11(2): 205-11.

30. Paulino DCR, Lopes MVO, Rolim ILTP. Biosafety and occupational accidents with sharp objects among nursing professionals at a university hospital in Fortaleza-ceará/brazil. Rev Cogitare Enferm. 2008; 13(4):507-13.

31. Gomes AC, Agy LL, Malagutti SE, Canini SRMS, Cruz EDA, Gir E. Acidentes Ocupacionais com Material Biológico e Equipe de Enfermagem de um Hospital Escola. Rev Enferm. 2009; $17(2): 220-3$.

32. Nicolle Luise Nowak et al. Fatores de risco para acidentes com materiais perfurocortantes. Rev. o Mundo da Saúde. 2013; 37(4):419-426.

33. Marziale MHP, Rodrigues CM. A produção científica sobre os acidentes de trabalho com material perfurocortante entre trabalhadores de enfermagem. Rev Latino-am Enfermagem. 2002; 10(4):571-77.

34. Farias GS, Oliveira CS. Occupational Hazards Related to Nursing Professional in ICU: A Review. Rev. Braz J Health. 2012; 3(1):12.

35. Alves SSM, Passos JP, Tocantins FR. Acidentes com perfurocortantes em trabalhadores de enfermagem: uma questão de biossegurança. Rev. Enfer UERJ. 2009; 17: 373-7.

36. Frickmann F, Wurm B, Victor Jeger, Lehmann B, Zimmermann $H$, Exadaktylos AK.. 782 consecutive construction work accidents: who is at risk? A 10-year analysis from a Swiss university hospital trauma unit. Swiss Med Wkly. 2012; 142:w13674. 
37. Celik K, Yilmaz F, Kavalci C, Ozlem M, Demir A, Durdu T et al. Occupational Injury Patterns of Turkey. World Journal of Emergency Surgery [ internet ] 2013 [ cited 2016 fev 12] 8(57):16. Available from: http://www.wjes.org/content/8/1/5.

38. Brasil. Portaria n 3.214 de 08 de junho de 1978 Normas Regulamentadoras -NR. In: Segurança E Medicina Do Trabalho. 29. ed. São Paulo: Atlas, 1995. 489 p. (Manuais de legislação, 16).

39. Silva EJ da, Lima MG, Marziale MHP. The concept of risk and its symbolic effects in accidents with sharp instruments. Rev. bras. enferm. 65(5): 809-6814. 2012

40. Organização internacional do trabalho. Sistema de Gestão da Segurança e Saúde no Trabalho: Um Instrumento para uma Melhoria Contínua. 2011

41. Cervera DPP, Parreira BDM, Goulart BF. Educação em saúde: percepção dos enfermeiros da atenção básica em Uberaba (MG). Ciência \& Saúde Coletiva 2011; 16(supl. 1): 1547-1554.

Publish in International Archives of Medicine

International Archives of Medicine is an open access journal publishing articles encompassing all aspects of medical science and clinical practice. IAM is considered a megajournal with independent sections on all areas of medicine. IAM is a really international journal with authors and board members from all around the world. The journal is widely indexed and classified Q1 in category Medicine. 